\title{
A NOTE ON ORTHOGRAPHY AND STYLE
}

Throughout this book I intentionally blur the boundaries between Fonland and Yorùbáland, two ethnic territories found in present-day Nigeria and in the Republic of Bénin. I chose to do this for several reasons: (1) I seek to dismantle the long-standing scholarly and colonial associations that have connected Yorùbáland to Nigeria only; (2) I aim to re-create the multiethnic and transnational space of Ouidah, Bénin, as it exists on the ground; and, finally, (3) I hope to engage with the long-standing literature on Yorùbá religion, especially Ifá divination, while still attending to the ways in which Ifá divination is practiced by both Yorùbá and Fon peoples in southern Bénin. Even so, I attempted to provide local names and religious concepts in both the Fon and Yorùbá languages, using linguistically correct diacritical marks, while placing the emphasized language (which tended to shift from conversation to conversation during my fieldwork) first, and the deemphasized language second. Moreover, I prefaced Fon words with "Fon" and Yorùbá words with "Yr." for additional clarity (e.g., Fon Fá; Yr. Ifá). In these ways, I hope that scholars of both Bénin and Nigeria, and of both Fon and Yorùbá speakers, might find the research I have presented here useful. The only exception to my use of diacritical marks is in my repeated use of "Fon." I chose not to write "Fon" using the correct diacritical marks (Fòn) so as to remain consistent with existing scholarly literature. By contrast—and, again, following scholarly precedence-I use diacritical marks when I write "Yorùbá."

While "Vodún" is more accurately known as vodúnsínsen (spirit worship) and its adherents described as vodúnsćnt’́ (those who follow the spirits' taboos), for simplicity I name the religion as "Vodún" and the religion's followers, drawing on French, as "Vodúnisants" instead of using the more problematic English terms "Vodúnists" or "Voodooists." Following these conventions, I use "Vodún" to represent the religion as it is found in West Africa; "Vodou" to represent the Haitian variant; and "Voodoo" to show when I am indexing the stereotypical and often racialized African religion 
within non-Africans' imaginations. To indicate when I am speaking about the religion, I capitalize "Vodún," and when I use the word to mean "spirit" or "divinity," I write vodún with a lowercase "v."

In addition to these stylistic choices, when possible, I have changed the names of certain ritual ingredients and altered the order in which ritual events occur. This was done to protect ritual secrets and to prevent my work from being used as a "ritual manual" by spiritual seekers. In this same vein, I have used pseudonyms for all individuals and most place-names, including the name of the village (Fátòmè) in which I worked. I have, however, maintained the actual names of all major cities and historical figures. 
Vodún 
This page intentionally left blank 